\title{
The role of $4 \mathrm{PL}$ provider as a mediation and supply chain agility
}

Firm, supply chain agility and $4 \mathrm{PL}$

\author{
Macide Berna Çağlar Kalkan \\ Department of Logistics, Baskent University, Ankara, Turkey, and \\ Kenan Aydin \\ Faculty of Economic and Administrative Sciences, Ylldiz Technical University, \\ Istanbul, Turkey
}

\begin{abstract}
Purpose - The aim of this study is to examine the role and capabilities of fourth party logistics (4PL) in the supply chain agility and firm performance. In addition to this, the relationship between supply chain agility and firm performance is also examined. This study aims to fulfill the gap in the literature about the studies on the relationship between 4PL capability dimensions, supply chain agility and business performance.

Design/methodology/approach - The study uses survey data from 58 senior executives and managers in the logistics and supply chain functions from 4PL service providers' customer firms in Turkey. The results are structural equation modeling using SmartPLS software. Snowball sampling method was used to collect survey data.

Findings - This study shows that integrator and supply chain infomediary are appropriate practices for mediating the impact of agile supply chain strategies, on firm performance. For supply chain practitioners, results indicate that firms benefit greatly if they consider the outsourcing, such as a 4PL partnership, in conjunction with their supply chain strategy.

Research limitations/implications - Time, cost and the presence of businesses located in different cities across Turkey in the sample of study and the existence of the tendency of enterprises not to participate in the research can be stated as the limitations of this study.

Originality/value - In the literature, studies on $4 \mathrm{PL}$ have been conducted in different fields which can be categorized as follows: 4PL solution development, reasons that facilitate and prevent the design and implementation of 4PL, scope of 4PL service delivery and profit and risk sharing from the structure of 4PL networks. Briefly, the studies focus on conceptualizing and differentiating of 4PL from 3PL before reaching a common definition. Motivation of this study is to fulfill the gap of literature about supply chain agility, firm performance relationship and mediation role of 4PL skill dimensions.
\end{abstract}

Keywords Fourth party logistics, Supply chain agility, Integrator, Supply chain infomediary

Paper type Research paper

\section{Introduction}

The supply chain is the flow and management of resources throughout the business processes, from obtaining the raw material to the delivery of the product to the end user, to maintain profitable business operations (New and Payne, 1995). Production, procurement, logistics, marketing, finance and human resources are all integral parts of the supply chain (Erdal,2014).

(C) Macide Berna Çağlar Kalkan and Kenan Aydın. Published in Modern Supply Chain Research and Applications. Published by Emerald Publishing Limited. This article is published under the Creative Commons Attribution (CC BY 4.0) license. Anyone may reproduce, distribute, translate and create derivative works of this article (for both commercial and non-commercial purposes), subject to full attribution to the original publication and authors. The full terms of this license may be seen at http:// creativecommons.org/licences/by/4.0/legalcode

The authors express their gratitude to the Prof. Dr Gökhan Özer and Assoc. Prof. Dr Arzu Karaman Akgül who actively participated in the research described herein and to the anonymous reviewers for their valuable comments on the paper. In carrying out this research, authors have been supported by Yıldız Technical University, Scientific Research Project Fund (BAP), Istanbul, Turkey (Project ID SDK2018-3386). 
MSCRA

2,2

100

Supply chain management and outsourcing are attracting attention as concepts began to be used together, especially in the last decade. This is an important future aspect for the two concepts of $4 \mathrm{PL}$.

The term 4PL is a term introduced by Accenture (Li et al.,2012). 4PL acts as a supply chain integrator. 4PL generates supply chain solution by managing third party resources, technologies and skills. The main property of 4PL has no assets (Mehmann, 2015).

Using 4PL allows companies to focus on customers' needs. It is said that the motivation behind the working with $4 \mathrm{PL}$ service providers is that companies are increasingly focusing on their core competencies. If the entity has external resources in its supply chain tasks, this does not mean that the ultimate responsibility for the rules rests with the outsourcing. Supply chain professionals know every aspect of the 4PL operations, set rules and know where products are located at every point of the cycle. The 4PL service provider manages all necessary logistics activities for a company, including third party logistics (3PL) management. 4PL offers design, engineering and creative solutions for end-to-end supply chain including order management, production and logistics - supply chain in the form of a nervous system. $4 \mathrm{PL}$ is responsible for daily management at the operational level and the company is responsible for international management at the strategic level. 4PL transfer the knowledge and experience gained by other companies in the business and also analyzes the processes, works with the staff of the business and trains them (Tanyaş and Düzgün, 2017).

The rest of the paper is organized as follows: Section II presents a brief review of the literature on supply chain agility, 4PL and firm performance. In Section III, we describe research method for this study. Results are presented with regards to the role of $4 \mathrm{PL}$ as they are discussed in the literature in Section IV. Main conclusions are offered in Section V.

\section{Theoretical background}

\subsection{Supply chain agility, 4PL and firm performance}

Firms use supply chain strategies to satisfy their customers more than their competitors. The decisions involved in this ensure the achievement of the marketing targets of firms. A typical supply chain strategy seeks to achieve a smooth flow with the minimum cost. On the other hand, nowadays customization is especially important in products and services. In a globally competitive environment, firms prefer methods such as outsourcing to develop supply chain strategies that are consistent with value proposition (Meyer et al., 2017).

Agility as a supply chain strategy means using market knowledge and virtual organizations taking advantage of profitable opportunities in a volatile market. Agility suggests cooperation to increase inter-organizational competitiveness (Ambe, 2010).

To survive under the influence of globalization and cost-cutting pressures, firms support external professionals as outsourcing in supply chain management (Skender et al., 2017).

The strategy includes decisions on the selection of suppliers, the location of the facilities and the choice of distribution channels. All of these decisions ensure the achievement of the marketing targets of enterprises. Agility is all about customer sensitivity - collaboration between people, information, companies - and adaptation to change. The ability to quickly align members, network and operations according to customers' dynamic and turbulent requirements is the agility of the supply chain.

Market-sensitivity, process integration, network and virtual-based structure are required for supply chain agility. This can be achieved through collaborative relationships, process integration, information integration and customer sensitivity in achieving customer-oriented goals. At this point, the capabilities of $4 \mathrm{PL}$ service providers are important for companies.

Thus, based on the definition of supply chain agility and 4PL, we propose the following hypotheses: 
H1. Supply chain agility has a positive and direct effect on integrator.

H2. Supply chain agility has a positive and direct effect on supply chain infomediary.

H3. Supply chain agility has a positive and direct effect on firm performance.
Firm, supply chain agility and $4 \mathrm{PL}$

\subsection{PL and firm performance}

$4 \mathrm{PL}$ serves as the integrator that brings together the needs of the client and the resources available through the 3PL providers, the IT providers and the elements of business process management. 4PLs build closer relationships between the participants along the supply chain, support cost-cutting initiatives and improve the flexibility to deal with supply and demand uncertainties (Win, 2008).

4PL has a positive impact on firm performance. First, 4PL allows senior management to focus on core competencies and for the provision of broader supply chain services. Also, 4PL improves customer service, builds competitiveness, increases revenue and reduces liabilities, operational cost, working capital and fixed capital. The management of multiple logistics providers is handled by a single organization by using 4PLs. 4PL provides continuous monitoring and improvement of supply chain processes, performance, costs and service level achievements and simplifies the industrial and industrial relations environment. Besides all of these, a more flexible working environment can be established by 4PL (Nowodziński, 2010). Beyond all these information, we propose the following hypotheses:

H4. Integrator has a positive and direct effect on firm performance.

H5. Supply chain infomediary has a positive and direct effect on firm performance.

\subsection{Mediation effect of $4 P L$}

Numerous studies have shown that supply chain agility helps to improve firm performance. Most studies have correlated supply chain agility directly to either achieving competitive advantage or enhancing firm performance (Qrunfleh and Tarafdar, 2013). Supply chain agility is likely to bring about 4PL's abilities impressed by collaborative relationships, process integration, information integration and helps to develop firm performance. Supply chain agility and responsiveness are directly related with awareness of supply chain integration and adoption of information technology in the supply chain. (Cheng et al., 2008). In the light of these information, one can say that $4 \mathrm{PL}$ capabilities mediate the relationship between supply chain agility and firm performance, to enhance firm performance. Thus, the following hypotheses are proposed:

H6. Supply chain agility has a positive and indirect effect on firm performance through the mediation of integrator.

H7. Supply chain agility has a positive and indirect effect on firm performance through the mediation of supply chain infomediary.

We next describe the rationale for the research hypotheses. Figure 1 provides a summary of the relationship between $\mathrm{H} 1, \mathrm{H} 2, \mathrm{H} 3, \mathrm{H} 4, \mathrm{H} 5, \mathrm{H} 6$ and $\mathrm{H} 7$ as described below.

\section{Research method}

In the literature, studies on 4PL have been conducted in different fields which can be categorized as 4PL solution development, reasons that facilitate and prevent the design and implementation of 4PL, scope of 4PL service delivery and profit and risk sharing from the structure of 4PL networks. Briefly, the studies focus on conceptualizing and differentiating of $4 \mathrm{PL}$ from 3PL before reaching a common definition. Motivation of this study is to fulfill the 
MSCRA

2,2

102

Figure 1.

Research model and hypotheses
The Role of 4PL Provider as a Mediation and Supply Chain Agility

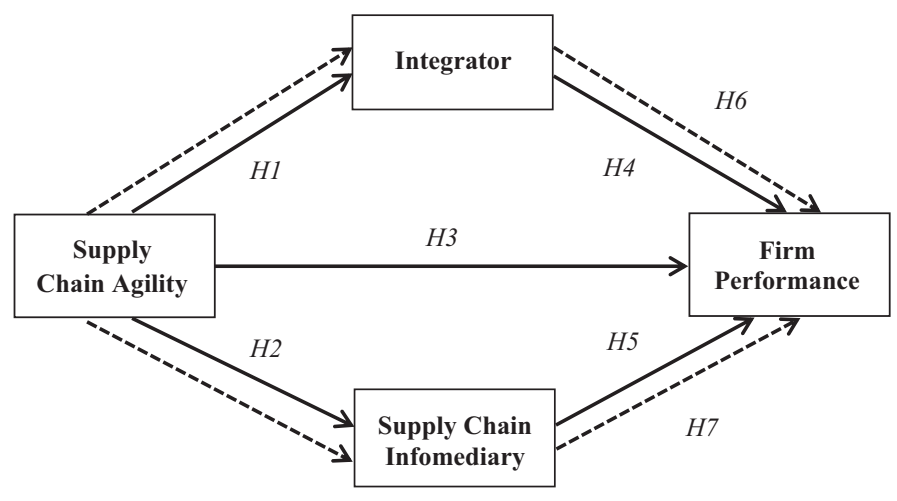

gap of literature about supply chain agility, firm performance relationship and mediation role of $4 \mathrm{PL}$ skill dimensions.

The snowball sampling method was used to collect survey data. Snowball sampling is a nonrandom sampling method that uses to help encourage other samples to take part in the study. This method is most applicable in populations that are difficult to access due to inaccessible professions (Taherdoost, 2016).

\subsection{Research model constructions}

Four main variable groups were used in this study. For first part of the survey, we asked the respondent to answer questions with demographic information of the firms.

One of the data collection technique used in this study was in-depth interviews, which were recorded and subsequently transcribed and analyzed (Kavak, 2003). Literature review developed in the previous section of the paper led us to focus on the executives of $4 \mathrm{PL}$ firms and logistics academic professionals. This approach enabled in-depth analysis of the capabilities of $4 \mathrm{PL}$ service provider how the perception of the logistics professionals. Interview participants included five executives from 4PL firms and one academic professional. In the second part of the survey, the instruments to measure capabilities of 4PL were generated from findings of these in-depth interviews.

For third part of the survey, firm performance were adopted from previous studies (Hazen and Byrd, 2012; Green Jr et al., 2006; Kim et al., 2006; Closs and Savitskie, 2003; Wisner, 2003). In addition to this, for last part of the survey, the items to measure supply chain agility and firm performance were generated from an extensive literature review of this topic (Braunscheidel and Suresh, 2009). All items were measured on Likert-type scales with response option ranging from 1 (strongly disagree) to 5 (strongly agree) (see Table I).

\section{Results}

In this section, we present the results obtained from the proposed model's analysis. We point out the profile of responders and exploratory and confirmatory factor analysis, as defined below. We then present some managerial insights.

\subsection{The profile of responder companies}

Table II summarizes the responder companies' characteristics in terms of their operating period, structure and employee size of companies. 
Demographic information of the firm

(1) Operating period

(2) Partnership structure

(3) Number of employees

Variables related to capabilities of $4 P L$ service providers (LSP)

(1) LSP establishes the objectives of the supply chain

(2) LSP informs us about an opportunity without expecting a benefit

(3) LSP gives advice on sectoral experience

(4) LSP provides experienced human resources

(5) LSP shares all kinds of risks with us

(6) LSP guides about time

(7) LSP monitors and controls supply chain processes

(8) LSP adapts quickly to new information technologies

(9) LSP makes information sharing customized

(10) LSP makes us aware of the importance of information sharing

(11) All logistics transactions are monitored in real time

(12) LSP makes accurate reporting about all processes

Variables related to supply chain agility

(13) We are able to leverage to competencies of our partners

(14) Joint planning with suppliers is important

(15) Information integration with suppliers is important

(16) Improving our level of customer service is a high priority

(17) Improving delivery reliability is a high priority

(18) Improving responsiveness to changing market needs is a high priority

(19) Increasing the level of customization is important

Variables related to Business Performance

(20) Increase in operating profitability

(21) Increase in return on investment

(22) Decrease in total costs

(23) Growth in sales

(24) Increased delivery reliability

Table I.

Variables of the study

\begin{tabular}{|c|c|c|c|c|}
\hline & Frequency & Percent & Cumulative & \\
\hline \multicolumn{5}{|l|}{ Operating period of firm (years) } \\
\hline $0-40$ years & 31 & 53.4 & 53.4 & \\
\hline $41-80$ years & 15 & 25.9 & 79.3 & \\
\hline 81 and more & 12 & 20.7 & 100.0 & \\
\hline Total & 58 & 100.0 & & \\
\hline \multicolumn{5}{|l|}{ Firm Structure } \\
\hline Domestic partnership & 24 & 41.4 & 41.4 & \\
\hline $50 \%$ domestic, $50 \%$ foreign partnership & 8 & 13.8 & 55.2 & \\
\hline $50 \%$ more domestic partnership & 3 & 5.2 & 60.3 & \\
\hline $50 \%$ more foreign partnership & 3 & 5.2 & 65.5 & \\
\hline Foreign partnership & 20 & 34.5 & 100.0 & \\
\hline Total & 58 & 100.0 & & \\
\hline \multicolumn{5}{|l|}{ Employee size } \\
\hline 1-2000 employees & 28 & 48.3 & 48.3 & Table II. \\
\hline 2001-4,000 employees & 12 & 20.7 & 69 & Operating period, \\
\hline 4,001 and more employees & 18 & 31 & 100 & structure and employee \\
\hline Total & 58 & 100.0 & & size of firm \\
\hline
\end{tabular}


MSCRA

2,2

104

In terms of size, 28 percent of the respondents reported that their firms have approximately 2,000 employees while 18 percent of them have more than 4,001 employees, which indicates that these firms are large-scaled companies.

In terms of firm structure, approximately 24 percent of the firms are established with Turkish capital while 20 percent of them are based on foreign partnerships.

According to the frequency analysis of the firms, approximately 31 percent of them are younger than 40 years while 15 percent of them are older than 40 years and 12 percent of them are older than 81 years. All of the results are summarized in Table II.

When one looks at the results given in Table II, percentage of companies with operating period up to 40 years and with number of employees up to 2,000 is high in the research sample.

\subsection{Exploratory factor analysis}

A statistical method is required to decide on the structure of the items in the scale dimensions and the number of factors. Therefore, in the scale development study, exploratory factor analysis is used primarily to discover the underlying hidden structure (Orçan, 2018) (see Table III).

First, the Kaiser-Meyer-Olkin (KMO) measure of sampling adequacy test and Bartlett's test of sphericity were done to see whether the data for variables were convenient for conducting factor analysis.

It was seen that KMO value was 0.838 and Bartlett's test of sphericity was significant $(p=0.000<0.001)$, this indicated that the data were adequate and appropriate to conduct factor analysis.

24 variables were prepared for the study and subjected to factor analysis. The data obtained as a result of this is intended to be more understandable and interpretable (see Table IV).

As a result of factor analysis, a total of 4 factors were obtained. The results show that those seven factors explain the 70.175 percent of the total variance. 4 factors obtained as a result of factor analysis are named as follows:

Factor 1: integrator: There are eight variables under this factor. It is seen that the expressions under the factor are related to the integrator capability of 4PL service providers. According to this, this factor is called integrator. The explained variance percentage of this factor was found to be 22.927 percent.

Factor 2: supply chain agility: There are 7 variables under this factor. It is seen that the expressions under the factor are associated with supply chain agility. According to this, this factor is called supply chain agility. The explained variance percentage of this factor was found to be 19.448 percent.

Factor 3: business performance: There are 5 variables under this factor. It is seen that the expressions under this factor are related to business performance. According to this, this factor is called business performance. The explained variance percentage of this factor was found to be 17.600 percent.

Factor 4: supply chain infomediary: There are 4 variables under this factor. It is seen that the expressions under the factor are related to the information provider capability of 4PL service providers. According to this, this factor is called supply chain infomediary. The explained variance percentage of this factor was found to be 10.200 percent.

Table III.

Kaiser-Meyer-Olkin (KMO) measure of sampling adequacy test and Bartlett's test of sphericity
Kaiser-Meyer-Olkin (KMO) test for sampling adequacy

Bartlett's test of sphericity

$$
\begin{aligned}
& 0.838 \\
& X^{2}=1129.540 \mathrm{df}=276 \\
& \text { Sig }=0.00
\end{aligned}
$$




\begin{tabular}{|c|c|c|c|c|c|c|}
\hline & Variables & 1 & 2 & 3 & 4 & Firm, supply \\
\hline$X 3$ & LSP gives advice on sectoral experience & 0.858 & & & & and $4 \mathrm{PL}$ \\
\hline$X 2$ & LSP informs us about an opportunity without expecting a benefit & 0.776 & & & & \\
\hline$X 6$ & LSP guides about time & 0.765 & & & & \\
\hline$X 12$ & LSP makes accurate reporting about all processes & 0.703 & & & & \\
\hline$X 10$ & LSP makes us aware of the importance of information sharing & 0.681 & & & & \\
\hline$X 8$ & LSP adapts quickly to new information technologies. & 0.653 & & & & 105 \\
\hline$X 5$ & LSP shares all kinds of risks with us & 0.592 & & & & \\
\hline$X 4$ & LSP provides experienced human resources & 0.564 & & & & \\
\hline$X 17$ & Improving delivery reliability is a high priority & & 0.890 & & & \\
\hline$X 18$ & $\begin{array}{l}\text { Improving responsiveness to changing market needs is a high } \\
\text { priority }\end{array}$ & & 0.878 & & & \\
\hline$X 16$ & Improving our level of customer service is a high priority & & 0.846 & & & \\
\hline$X 15$ & Information integration with suppliers is important & & 0.792 & & & \\
\hline$X 14$ & Joint planning with suppliers is important & & 0.781 & & & \\
\hline$X 13$ & We are able to leverage to competencies of our partners & & 0.556 & & & \\
\hline$X 19$ & Increasing the level of customization is important & & 0.534 & & & \\
\hline$X 21$ & Increase in return on investment & & & 0.876 & & \\
\hline$X 20$ & Increase in operating profitability & & & 0.819 & & \\
\hline$X 22$ & Decrease in total costs & & & 0.789 & & \\
\hline$X 23$ & Growth in sales & & & 0.726 & & \\
\hline$X 24$ & Increased delivery reliability & & & 0.575 & & \\
\hline$X 11$ & All logistics transactions are monitored in real time & & & & 0.716 & \\
\hline$X 1$ & LSP establishes the objectives of the supply chain & & & & 0.615 & Table IV. \\
\hline$X 9$ & LSP makes information sharing customized & & & & 0.570 & The factor structure of \\
\hline$X 7$ & LSP monitors and controls supply chain processes & & & & 0.545 & variables \\
\hline
\end{tabular}

\subsection{Confirmatory factor analysis}

Our PLS-SEM model is evaluated by considering the internal consistency (composite reliability), indicator reliability, convergent validity and discriminant validity, using SmartPLS.

In PLS-SEM measurement model evaluations, first, the internal consistency reliability is checked. The values of Cronbach's alpha of each factor were between 0.865 and 0.922 . It is a different measure which can be interpretable similarly as Cronbach's alpha; Composite reliability values were between 0.908 and 0.936 . It can be said that internal consistency reliability is provided.

Besides, factor loadings of each indicator (items of the scale) should be higher than 0.60 , and AVE values should be higher than 0.50 (Hair et al., 2014) (see Table IV).

The factor loadings were between 0.749 and 0.895 because the AVE values were between 0.636 and 0.712 , which was considered as sufficient evidence for convergent validity (Table V).

In a reflective measurement model, the problem of indicator collinearity may occur if the indicators are highly correlated to each other. For this purpose, variance inflation factor (VIF) values were examined. VIF value lower than 5 shows that there is no collinearity problem. If the VIF value is greater than 5 , it is recommended to remove the relevant items from the model (Hair et al., 2011). So there is one item higher than the threshold value that was removed from the research model.

Path coefficients were calculated by a series of multiple regression analyses based on the hypothesized model. The final results were presented in Figure 2.

As seen in Table VI, the values in parentheses are the square root of AVE. Fornell and Larcker (1981) suggest that the square root of AVE in each latent variable can be used to establish discriminant validity if this value is larger than other correlation values among the 


\begin{tabular}{|c|c|c|c|c|c|}
\hline & & & & & \\
\hline $\begin{array}{l}\text { MSCRA } \\
2\end{array}$ & & Factor & Cronbach's $\alpha$ & $\mathrm{CR}$ & AVE \\
\hline & Integrator & & 0.922 & 0.936 & 0.647 \\
\hline & (1) Item & 0.810 & & & \\
\hline & (2) Item & 0.757 & & & \\
\hline & (3) Item & 0.804 & & & \\
\hline & (4) Item & 0.863 & & & \\
\hline 106 & (5) Item & 0.803 & & & \\
\hline & (6) Item & 0.749 & & & \\
\hline & (7) Item & 0.871 & & & \\
\hline & (8) Item & 0.768 & & & \\
\hline & Supply Chain Agility & & 0.883 & 0.912 & 0.636 \\
\hline & $\begin{array}{l}\text { (1) Item } \\
\text { lats }\end{array}$ & 0.764 & & & \\
\hline & (2) Item & 0.855 & & & \\
\hline & (3) Item & 0.874 & & & \\
\hline & (4) Item & 0.777 & & & \\
\hline & (5) Item & 0.857 & & & \\
\hline & (6) Item & 0.632 & & & \\
\hline & Supply Chain Infomediary & & 0.865 & 0.908 & 0.712 \\
\hline & (1) Item & 0.798 & & & \\
\hline & (2) Item & 0.857 & & & \\
\hline & (3) Item & 0.884 & & & \\
\hline & (4) Item & 0.834 & & & \\
\hline Table V. & Business Performance & & 0.894 & 0.922 & 0.703 \\
\hline Factor loadings, & (1) Item & 0.896 & & & \\
\hline Cronbach's $\alpha$, & (2) Item & 0.876 & & & \\
\hline composite reliability & (3) Item & 0.867 & & & \\
\hline and AVE values of & (4) Item & 0.773 & & & \\
\hline the scale & (5) Item & 0.774 & & & \\
\hline
\end{tabular}

latent variables. As can be seen in Table VI, each factor's square root is larger than other correlation values.

Henseler et al. (2015) propose the heterotrait-monotrait ratio of correlations (HTMT) as a new approach to assess discriminant validity in variance-based SEM.

Authors suggest a threshold of HTMT of 0.90; in terms of content far away from each other, they should be below 0.85 . In Table VII HTMT values are below the threshold value. As can be seen in Tables VI and VII, the result indicates that discriminant validity is well established.

\subsection{Hypothesis testing}

SmartPLS 3 is used for testing the hypotheses, and the results are presented in Tables VIII and IX. To test the significance of the structural model, the bootstrapping resampling method was used with 5,000 subsamples.

The results of hypothesis testing with the standardized path coefficients and $p$-values were appropriate.

H1 suggests that supply chain agility has a positive and direct effect on integrator, which is supported as the aupply chain agility's effect on integrator is $0.544(\phi<0.05)$.

$\mathrm{H} 2$ suggests that supply chain agility has a positive and direct effect on supply chain infomediary, which is supported as the supply chain agility's effect on supply chain infomediary is $0.449(p<0.05)$.

H3 suggests that supply chain agility has a positive and direct effect on firm performance, which is supported as the integrator's effect on business performance is $0.463(p<0.05)$. 


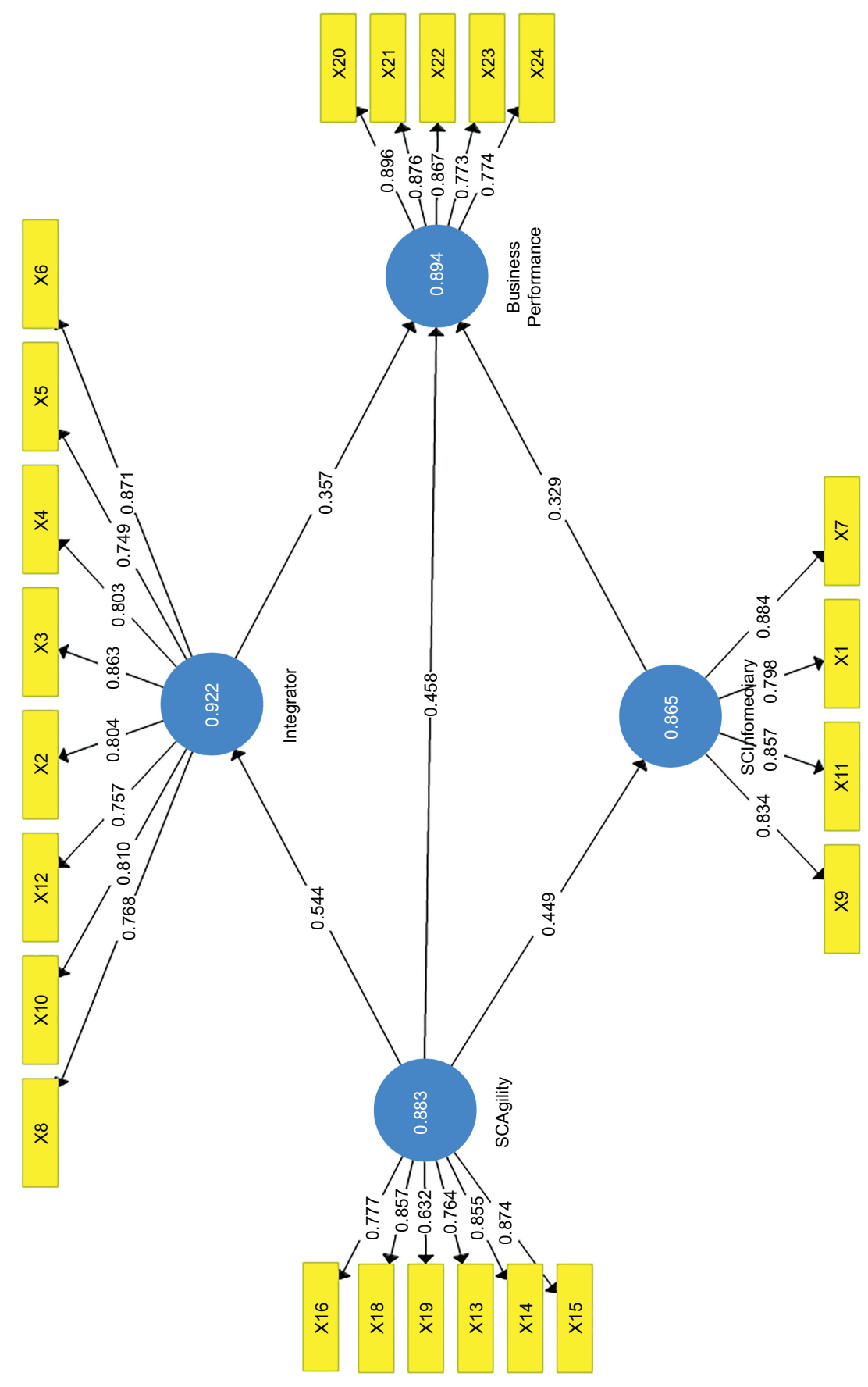

Firm, supply chain agility and $4 \mathrm{PL}$

Figure 2.

The path model of this study 
MSCRA

2,2

108

H4 suggests that integrator has a positive and direct effect on firm performance, which is supported as the integrator's effect on firm performance is $0.357(p<0.05)$.

H5 suggests that supply chain infomediary has a positive and direct effect on firm performance, which is supported as the integrator's effect on firm performance is $0.329(p<0.05)$.

All values of $Q^{2}$ in Table IX are above zero, providing support for the model's predictive relevance regarding the latent variables.

The model's predictive power is reflected by the variables' $R$-squared values (Hair et al., 2014). The effect size of firm performance can be classified as large; the effect sizes of integrator and supply chain infomediary are close to medium (Wetzls et al., 2009) (see Table X).

\begin{tabular}{lcccc}
\hline & $\begin{array}{c}\text { Firm } \\
\text { performance }\end{array}$ & $\begin{array}{c}\text { Supply chain } \\
\text { Integrator }\end{array}$ & $\begin{array}{c}\text { Supply chain } \\
\text { infomediary }\end{array}$ \\
\hline Firm performance & $(0.839)$ & & & \\
Integrator & 0.668 & $(0.804)$ & & \\
Supply chain agility & 0.458 & 0.544 & $(0.797)$ & 0.844 \\
Supply chain & 0.650 & 0.753 & 0.449 & \\
infomediary & & & & \\
\hline
\end{tabular}

\section{Table VI.}

Fornell-Larcker criterion analysis for checking discriminant validity

\begin{tabular}{cccc} 
Firm & & Supply Chain & Supply Chain \\
performance & Integrator & Agility & Infomediary \\
\hline
\end{tabular}

Table VII.

Heterotrait-monotrait ratio of correlations (HTMTs) for checking discriminant validity
Firm performance

Integrator

Supply chain agility

Supply chain

infomediary
0.712

$0.498 \quad 0.584$

$0.726 \quad 0.834$

0.507
Table VIII.

Significance testing results of the structural model path coefficients for direct effect

\begin{tabular}{lcccc}
\hline Variables & $\beta$ & Std. error & $t$ & $p$ \\
\hline Integrator $\rightarrow$ firm performance & 0.357 & 0.170 & 2.644 & 0.018 \\
Supply chain infomediary $\rightarrow$ Firm performance & 0.329 & 0.160 & 2.254 & 0.020 \\
Supply chain agility $\rightarrow$ Firm performance & 0.463 & 0.084 & 5.533 & 0.000 \\
Supply chain agility $\rightarrow$ Integrator & 0.544 & 0.098 & 5.550 & 0.000 \\
Supply chain agility $\rightarrow$ Supply chain infomediary & 0.449 & 0.128 & 3.508 & 0.000 \\
\hline
\end{tabular}

Table IX.

Significance testing results of the $R^{2}, f^{2}, Q^{2}$ and VIF

\begin{tabular}{lcccc}
\hline Variables & $R^{2}$ & $f^{2}$ & $Q^{2}$ & VIF \\
\hline Integrator $\rightarrow$ Firm performance & 0.505 & 0.098 & 0.314 & 2.635 \\
Supply chain infomediary $\rightarrow$ Firm performance & & 0.094 & & 2.325 \\
Supply chain agility $\rightarrow$ Firm performance & & 0.019 & & 1.427 \\
Supply chain agility $\rightarrow$ Integrator & 0.296 & 0.420 & 0.170 & 1.000 \\
Supply chain agility $\rightarrow$ Supply chain infomediary & 0.202 & 0.253 & 0.131 & \\
\hline
\end{tabular}


H5 assumes that supply chain agility has an indirect effect on firm performance through the mediation of an integrator. $\mathrm{H} 6$ assumes that supply chain agility has an indirect effect on firm performance, through the mediation of a supply chain infomediary. To validate H5 and H6, the mediating role of integrator and supply chain infomediary on the relationship between supply chain agility and firm performance was analyzed, following the steps suggested by but based on bootstrapping (Hair et al., 2014).

The relative size of the mediating effect is decided by calculating the variance accounted for (VAF). The result of the analysis suggests that integrator and supply chain infomediary fully mediates the effect (VAF: 1) of supply chain agility on firm performance; thus, $\mathrm{H} 6$ and $\mathrm{H} 7$

\section{Conclusion}

In this study, the capability dimensions of $4 \mathrm{PL}$ service providers and the concepts to be considered to measure these dimensions are examined. To measure the capabilities of 4PL service providers, the scale development process was designed and implemented including the concepts existing in the literature.

First of all, the concept of 4PL and explaining the studies in the literature about 4PL can be considered as the theoretical contribution of this study. This contribution, as well as logistics activities carried out in the presence, detected in
Turkey but held on because of much emphasis on the size of 4PL capabilities in the literature, This contribution, as well as logistics activities carried out in the presence, detected in
Turkey but held on because of much emphasis on the size of 4PL capabilities in the literature, can be stated as another contribution.

Findings obtained at the end of the study reveal the effect of the capability dimensions of 4PL service providers on the performance of the customer companies. The fact that this study is the first attempt to develop the scale of talent dimensions of the first 4PL service providers in Turkey can be stated as another contribution. In light of the findings obtained in this study, it can be said that only if companies realize supply chain integration and adopt information technology in the supply chain and have an agile supply chain, they can receive 4PL service and 4PL service providers can fully demonstrate their capabilities.

It is seen in the literature that the definitions of $4 \mathrm{PL}$ and leading logistics service provider are not completely separated from each other. In particular, the concept of $4 \mathrm{PL}$ is relatively a new topic in the literature. In addition, $4 \mathrm{PL}$ approaches require a very reliable supplier-customer relationship. If it is assessed in terms of Turkey, it can be said that the process of $4 \mathrm{PL}$ applications proceeds differently compared to the applications in the world. The reason for this may be the protective understanding of customer companies regarding co-operation and information sharing with their supply chain partners. At this point, it can be said that the perspective of the top management of customer companies and the supply chain management strategy of the companies are of great value for the healthy operation of the process. Therefore, in this study, it was emphasized that the questionnaire was answered by the top managers of the companies who are the customers of $4 \mathrm{PL}$ service providers.

It is recommended that the scale obtained in the future studies can be tested on different samples and models and applied in different cultures.

Thus, the generalization of the scale can be ensured through different studies considering different sample groups.

\begin{tabular}{lcccc}
\hline Variables & $\beta$ & Std. error & $t$ & $p$ \\
\hline Supply chain agility $\rightarrow$ Integrator $\rightarrow$ Firm performance & 0.194 & 0.097 & 1.996 & 0.023 \\
Supply chain agility $\rightarrow$ Supply chain infomediary $\rightarrow$ Firm performance & 0.148 & 0.082 & 1.791 & 0.037
\end{tabular}

\begin{abstract}
are supported.
\end{abstract}
Firm, supply chain agility and $4 \mathrm{PL}$ 
MSCRA

2,2

110

\section{References}

Ambe, I.M. (2010), "Agile supply chain: strategy for competitive advantage", Journal of Global Strategic Management, Vol. 4 No. 1, pp. 5-17.

Braunscheidel, M.J. and Suresh, N.C. (2009), "The organizational antecedents of a firm's supply chain agility for risk mitigation and response", Journal of Operations Management, Vol. 27 No. 2, pp. 119-140.

Cheng, J.H., Chen, S.S. and Chuang, Y.W. (2008), “An application of fuzzy Delphi and fuzzy AHP for multi-criteria evaluation model of fourth-party logistics", WSEAS Transactions on Systems, Vol. 7 No. 5, pp. 466-478.

Closs, D.J. and Savitskie, K. (2003), "Internal and external logistics information technology integration”, The International Journal of Logistics Management, Vol. 14 No. 1, pp. 63-76.

Erdal, M. (2014), Satmalma ve Tedarik Zinciri Yönetimi, Beta, İstanbul.

Fornell, C. and Larcker, D.F. (1981), "Evaluating structural equation models with unobservable variables and measurement error", Journal of Marketing Research, Vol. 18 No. 1, pp. 39-50.

Green Jr, K.W., McGaughey, R. and Casey, K.M. (2006), "Does supply chain management strategy mediate the association between market orientation and organizational performance?”, Supply Chain Management: An International Journal, Vol. 11 No. 5, pp. 407-414.

Hair, J.F., Tomas, G., Hult, M., Ringle, C.M. and Sarstedt, M. (2014), A Primer on Partial Least Square Structural Equations Modeling (PLS-SEM), Sage, Los Angeles, LA.

Hair, J.F., Ringle, C.M. and Sarstedt, M. (2011), "PLS-SEM: indeed a silver bullet”, Journal of Marketing Theory and Practice, Vol. 19 No. 2, pp. 139-152.

Hazen, B.T. and Byrd, T.A. (2012), "Toward creating competitive advantage with logistics information technology", International Journal of Physical Distribution and Logistics Management, Vol. 42 No. 1 , pp. 8-35.

Henseler, J., Ringle, C.M. and Sarstedt, M. (2015), "A new criterion for assessing discriminant validity in variance-based structural equation modelling", Journal of the Academy of Marketing Science, Vol. 43, pp. 115-135.

Kavak, B. (2003), Pazarlama Ve Pazar Araştırmalan Tasarım Ve Analiz, Detay Yayıncılık, Ankara.

Kim, D., Cavusgil, S.T. and Calantone, R.J. (2006), "Information system innovations and supply chain management: channel relationships and firm performance", Journal of Academy of Marketing Science, Vol. 34 No. 1, pp. 40-54.

Li, W., Wu, M.Y. and Mei, Q. (2012), "The research of supply chain based on fourth party logistics optimization", Advanced Materials Research, Trans Tech Publications, Vol. 461, pp. 393-397.

Mehmann, J. (2015), "Adoption of fourth party logistics in the sector of German agricultural bulk logistics - a technology-organization-environment framework approach", Wirtschaftsinformatik, pp. 1498-1512.

Meyer, A., Niemann, W. and Peckover, K. (2017), "Supply chain agility: a conceptual framework towards leagility", 1st African Operations Management Conference, held at Misty Hills, Johannesburg, 2-4 Oct 2017, pp. 1-16.

New, J.S. and Payne, P. (1995), "Research frameworks in logistics: three models, seven dinners and a survey", International Journal of Physical Distribution and Logistics Management, Vol. 25 No. 10, pp. 60-77.

Nowodziński, P. (2010), "Strategic dimensions of fourth-party logistics, advanced logistics systems", Theory and Practice, Vol. 4, pp. 114-115.

Orçan, F. (2018), "Exploratory and confirmatory factor analysis: which one to use first?", Eğitimde ve Psikolojide Ölçme ve Değerlendirme Dergisi, Vol. 9 No. 4, pp. 414-421. 
Qrunfleh, S. and Tarafdar, M. (2013), "Lean and agile supply chain strategies and supply chain responsiveness: the role of strategies supplier partnership and postponement”, Supply Chain Management: An International Journal, Vol. 18 No. 6, pp. 571-582.

Skender, H.P., Mirkovic, P.A. and Prudky, I. (2017), "The role of the 4PL model in a contemporary supply chain", Scientific Journal of Maritime Research, Vol. 31, pp. 96-101.

Taherdoost, H. (2016), "Sampling methods in research methodology; how to choose a sampling technique for research", International Journal of Academic Research in Management, Vol. 5 No. 2, pp. 18-27.

Tanyaş, M. and Düzgün, M. (2017), Tedarik Zinciri Yönetimi En İyi Uygulamalar, Nobel Akademik Yayıncılık Eğitim Danışmanlık Tic. Şti, İstanbul.

Wetzels, M., Odekerken-Schröder, G. and Oppen, C.V. (2009), "Using PLS path modeling for assessing hierarchical construct models: guidelines and empirical illustration”, MIS Quarterly, Vol. 33, pp. 177-195.

Win, A. (2008), “The value a 4PL provider can contribute to an organization”, International Journal of Physical Distribution and Logistics Management, Vol. 38 No. 9, pp. 674-684.

Wisner, J.D. (2003), "A structural equation model of supply chain management strategies and firm performance", Journal of Logistics, Vol. 24 No. 1, pp. 1-26.

\section{Further reading}

Thatte, A.A., Rao, S.S. and Ragu-Nathan, T.S. (2013), "Impact of SCM practices of a firm on supply chain responsiveness and competitive advantage of a firm", Journal of Applied Business Research, Vol. 29 No. 2, p. 499.

\section{Corresponding author}

Macide Berna Çağlar Kalkan can be contacted at: mbernakalkan@gmail.com
Firm, supply chain agility and $4 \mathrm{PL}$ 